\title{
Perioperative planning for cardiovascular operations in the COVID-19 pandemic
}

\author{
COVID-19 pandemisinde kardiyovasküler ameliyatların perioperatif planlaması
}

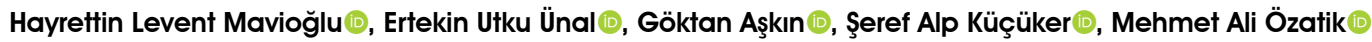 \\ Department of Cardiovascular Surgery, Ankara City Hospital, Ankara, Turkey
}

\begin{abstract}
Coronavirus disease-2019 (COVID-19) is a serious health concern which alert all healthcare professionals worldwide. There are two main issues caused by this pandemic regarding for the healthcare system. First, it is a necessity to postpone many elective procedures/surgeries to reduce the burden of the healthcare system which may be confronted with strain by the increased speed of transmission. Therefore, we aimed to develop an algorithm called as Level of Priority to identify the priority and deferrability of cardiovascular diseases requiring surgery. Second, it is essential to perform surgery and intensive care unit follow-up in a setting where the infection prevention measures are followed for primary patients requiring emergency cardiovascular surgery. In this article, we present necessary precautions to be exercised to provide the patient safety and the highest level of protection for the surgical team.
\end{abstract}

Keywords: Cardiovascular surgical procedures, covid-19, pandemic, personal protective equipment.

A novel coronavirus, initially reported in Wuhan, China, has resulted in an ongoing outbreak starting from late December 2019. The causative microorganism has been identified as severe acute respiratory syndrome coronavirus 2 (SARS-CoV-2). ${ }^{[1]}$ The World Health Organization (WHO) has currently announced that the situation has become a pandemic. ${ }^{[2]}$ Of note, coronavirus disease-2019 (COVID-19) has caused over 42,000 deaths in 857,641 confirmed patients worldwide, whereas the first case of COVID-19 was reported on March $11^{\text {th }} 2020$ in Turkey. ${ }^{[3]}$

\section{$\ddot{O} Z$}

Koronavirüs hastalı̆̆ı-2019 (COVID-19) tüm dünyada sağlık çalışanlarını alarm durumuna geçiren ciddi bir sağlık sorunudur. Pandeminin beraberinde getirmiş olduğu ve sağlık sistemini ilgilendiren ele alınması gereken iki önemli konu mevcuttur. Birincisi; pandeminin yayılma hızına yetişme sıkıntısıçekebilecek olan sağlık sisteminin yükünü azaltabilmek açısından elektif birçok işlemin/cerrahinin ertelenmesi gerekliliğidir. Bu nedenle, cerrahi gereken kardiyovasküler hastalıkların önceliğinin ve ertelenebilirliğinin belirlenmesi için "Öncelik Düzeyi” olarak adlandırdı ğımız bir algoritma geliştirilmesini amaçladık. İkinci olarak ise; kardiyovasküler cerrahi yapılması gereken acil ve öncelikli hastalarda cerrahinin ve sonrasında yoğun bakım ünitesinde takibinin, enfeksiyon koruma tedbirlerinin sağlandığı bir ortamda yapılması gerekliliğidir. Bu yazıda, hasta güvenliğinin sağlanabilmesi ve cerrahi ekibin maksimum seviyede korunabilmesi için uygulanabilecek olan gerekli tedbirler sunuldu.

Anahtar sözcükler: Kardiyovasküler cerrahi işlemler, covid-19, yaygın, kişisel koruyucu ekipman.

COVID-19 is a tremendously challenging health problem which has aroused the interest of producing epidemiological reports by the healthcare workers. In addition, the prevention measures and treatment algorithms have been updated by authorities day by day. ${ }^{[3-5]}$ Although there are ongoing debates, the guidelines for anesthetic and airway management are considered to be well-documented. ${ }^{[6-9]}$ However, the structure of the operating room (OR) and need for surgical steps for the surgeon have been neglected until now. ${ }^{[10-12]}$ Likewise, there is no available algorithm

Received: March 25, 2020 Accepted: March 31, 2020 Published online: April 03, 2020

Correspondence: Ertekin Utku Ünal, MD. Ankara Şehir Hastanesi Kalp ve Damar Cerrahisi Kliniği, 06800 Çankaya, Ankara, Türkiye. Tel: +90 532 - 6570637 e-mail: utkuuna|@gmail.com 
for urgent/emergency cardiac surgeries in COVID-19 patients.

It is evident that a suspected/confirmed COVID-19 patient should be assessed by a specific procedure for any kind medical or surgical intervention. This report aims to provide an overview for the optimal prevention circumstances for a COVID-19 patient requiring cardiovascular surgery and prevention for cardiovascular healthcare workers, as well.

All the recommendations for COVID-19 patients in this article are developed with expert opinions and should be reconsidered individually for each patient. The up-to-date information needs to be strictly followed via the publications and websites of the WHO, Centers for Disease Control and Prevention (CDC), and Ministry of Health of Turkey. ${ }^{[3-5]}$

\section{GENERAL MEASURES TAKEN BY GOVERNMENT AND HOSPITAL MANAGEMENT}

General measures have been taken by both the administration of healthcare institutions and the government. The main concern of these measures is to handle the estimated increased numbers of COVID-19 patients with the capacity of the currently existing healthcare system. In this respect, as a first step, all elective surgeries have been postponed to an appropriate time period, as much as possible. ${ }^{[13]}$ Then, the definition of "pandemic hospital" has been made which consists of all tertiary centers (state, university, or private hospital) with intensive care unit (ICU) and medical staff (any two of Infectious Diseases Specialist, Internal Medicine Specialist, or Pulmonology Specialist) by the Ministry of Health of Turkey. ${ }^{[14]}$ The number of visitors and visiting time periods were also restricted. To cope with the probable decreases in the number of medical staff due to possibility of exposure of SARS-CoV-2 and to prepare for a spike in these cases, proper arrangements such as shifts for workplaces, social distancing during breaks, and limiting outpatient visits have been modified. Additionally, everyday-changing protocols and guidelines for the disease, announcements of government, and reading materials are currently shared by the instant messaging applications along with the medical staff.

\section{DEFERRABLE PROCEDURES AND TIMING OF CARDIOVASCULAR SURGICAL PROCEDURES}

It is not conceivable to define surgical urgency specially on specific diagnosis of the patient. Some surgical conditions may be postponed indefinitely for general surgical procedures; however, cardiovascular surgical patients are associated with relatively progressive disease. The need of surgery for a given disease condition should be recognized by an experienced surgeon to establish the risks which will be encountered with a delay. The risk to the patient and the risk for the healthcare providers should be given full consideration, as well. The decision to postpone or perform a cardiovascular surgical procedure needs to be implanted with respect to the patient's status and the capacity of the healthcare system. That is to say, decision-making strategies should not be exclusively contingent upon only COVID-associated risks, but rather on healthcare system capacities. Regarding the capacities healthcare system, the definitive decision should be based on medical staff (i.e., surgeon, ICU or perfusion), anesthesia staffing, ICU beds and need for isolation beds, surgical/anesthesia equipment (i.e., ventilators, pumps, extracorporeal membrane oxygenation, or intra-aortic balloon pump [IABP]), supplies (i.e., sutures, drapes, grafts, or valves), and blood and blood product availability.

The surgical decision-making process should be introduced to triage urgent/emergency conditions for cardiovascular surgery. ${ }^{[15]}$ In our routine practice, urgent/emergency procedures are well-defined by our international guidelines. ${ }^{[16-18]}$ However, we need to discuss the current extraordinary situation with the available limited data and expert opinions in the light of our published guidelines.

The Level of Priority (LoP) must be determined for the planned cardiovascular interventions (Figure 1). A classification of the cases may be helpful for us in that stage. According to this type of classification, LoP I refers to elective cases, LoP II refers to urgent cases, LoP III refers to emergent cases, and LoP IV refers to salvage cases. The definitions of the widely seen cardiovascular interventions are shown in Table 1. Following the definitions of LoP, LoP I cases should be postponed as much as possible, whereas LoP II, LoP III, and LoP IV cases should be operated with protective measures.

All patients should be discussed by the Heart Team to decide whether surgery should be delayed and also timing of the surgical procedure. For both non-COVID-19 and suspected/confirmed COVID-19 patients who strictly need cardiovascular interventions, there are some issues to consider. If the patient is classified as elective case ( $\mathrm{LoP} \mathrm{I}$ ), postponing the intervention is recommended within the current healthcare institution described as a pandemic hospital. 


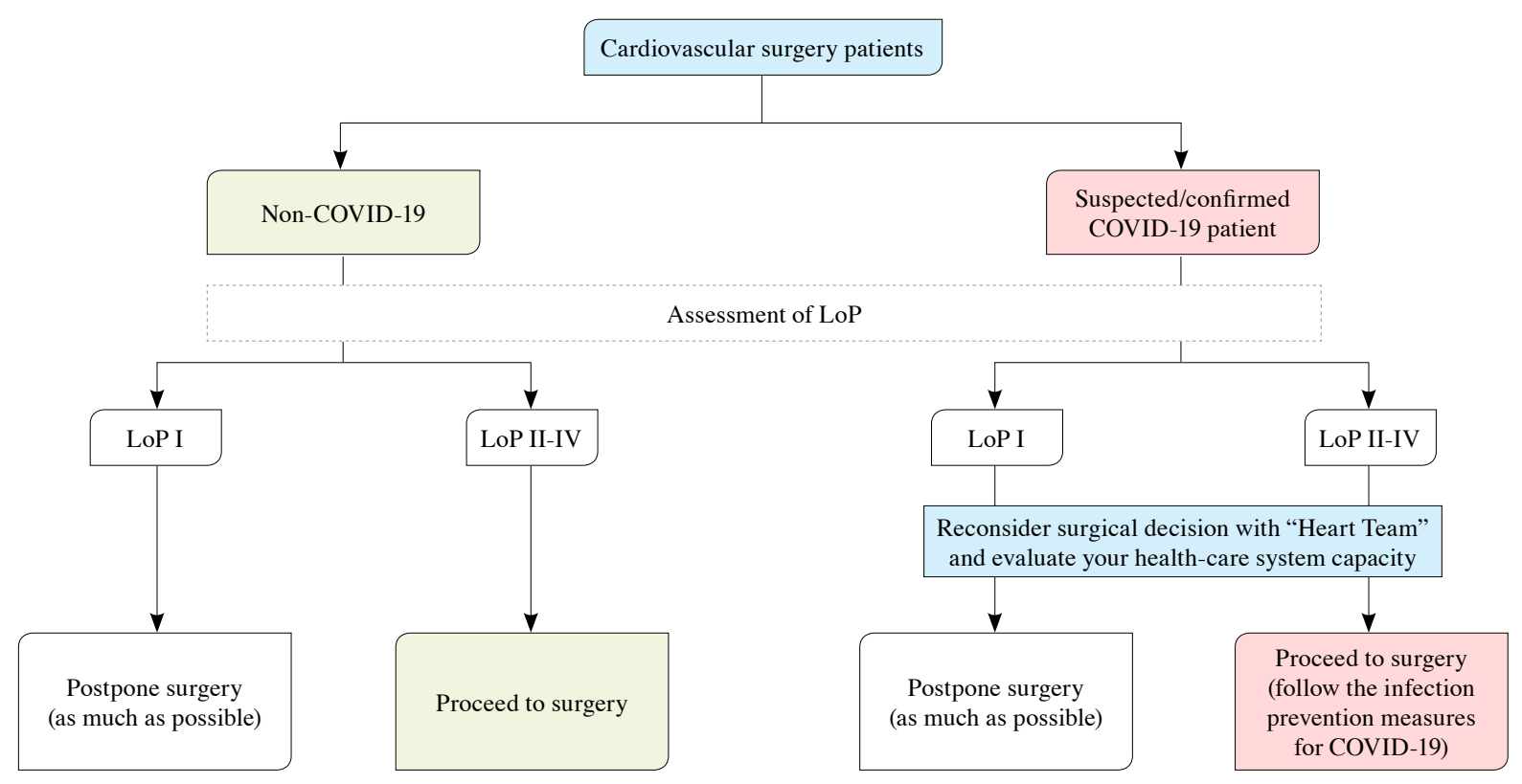

Figure 1. Algorithm of cardiovascular surgery patients in COVID-19 pandemic.

If the patient is classified as urgent/emergency/salvage case (LoP II-IV), planning the intervention within the current healthcare institution following the infection prevention measures is recommended. Thus, the risk for contamination which may occur during patient transport can be eliminated.

\section{PREPARATION OF OR FOR \\ CARDIOVASCULAR SURGERY}

Considering in-hospital spread of the virus, precautions should be taken to prevent nosocomial transmission both for the patient and the healthcare workers. A separate OR (COVID-19 OR) for the suspected/confirmed COVID-19 patients must be isolated with the pre-allocated transport routes for the patient. COVID-19 OR should be marked with warning signs of COVID-19. Feasibility of the OR setup and workflow is an important issue for all surgical procedures. Distribution of the surgical devices and anesthetic equipment should be unique for the predefined COVID-19 OR. All non-essential surgical and anesthetic equipment should be taken out from the OR. Coordination of healthcare workers, workflow of the COVID-19 OR, and designated personnel working at the COVID-19 OR should be planned day by day. Workflow of the COVID-19 OR includes routine universal infection prevention practices, donning and doffing personal protective equipment (PPE), and decontamination after the procedures. ${ }^{[6,19]}$ The procedure should be endeavored by limited number of healthcare workers (i.e., surgeon, anesthesiologist, perfusionist, and scrub nurse). All the necessary items such as intubation items, peripheral arterial/ central venous cannulation, syringes, gauze, surgical drapes, surgical instruments, sutures, cannulas for cardiopulmonary bypass (CPB), oxygenator and circuit for $\mathrm{CPB}$, prosthetic grafts and valves should be presettled before the patient enters to the OR. The traffic across the OR should be minimized. High-touch equipment such as anesthesia workstation, infusion pumps, CPB machine, cell-saver device, IABP, heatexchangers and computer equipment for documentation should be wrapped with plastic sheets to facilitate decontamination and also for possible contamination during the preoperative patient transportation. Strict anesthesia management and infection control procedures should be implanted for the suspected/ confirmed COVID-19 patients. . $^{[6,8,20,21]}$

\section{INTRAOPERATIVE MEASURES}

\section{Measures of infection prevention both for anesthesia and surgery}

Standard procedures (i.e., standard OR, standard method, and standardized anesthesia procedure) should be applied to non-COVID-19 patients.

The staff performing tracheal intubation and surgery should be covered by Level III protection including a disposable surgical cap, N95 mask, 


\section{Table 1. Definition of Surgical Timing and Level of Priority (LoP)}

LoP I - Elective Surgery (routine admission for operation)

Coronary artery disease (CAD)

- Patients with asymptomatic or stable angina

Valvular heart disease (VHD)

- Chronic and hemodynamically stable patients

Aneurysmal vascular disease (AVD)

- Unruptured and hemodynamically stable patients

Peripheral arterial disease (PAD)

- Patients with intermittent claudication

- Chronic limb ischemia with rest pain or tissue loss

- Asymptomatic bypass graft/stent restenosis

AV Access for hemodialysis

- Fistulas revision for malfunction/steal

- AV fistula and graft placement for dialysis

LoP II - Urgent Surgery (patients who have not been electively admitted for operation but who require intervention or surgery on the current admission for medical reasons. These patients cannot be discharged without a definitive procedure)

CAD

- Acute Coronary Syndromes (NSTEMI, STEMI, USAP) (timing of the procedure should be decided on an individual basis, according to symptoms, hemodynamic stability, coronary anatomy, and signs of ischemia and failed/unsuitable for percutaneous intervention) such as; severe left main (LM) or three-vessel CAD involving the proximal left anterior descending artery (LAD).

VHD

- Acute aortic regurgitation

- Acute mitral regurgitation

- Obstructive prosthetic valve thrombosis in critically ill patients without serious comorbidity

- Active endocarditis

AVD

- Thoraco-abdominal aortic aneurysm (TAAA)/abdominal aortic aneurysm (AAA) with acute contained rupture with hemodynamically stable patients

- Rapid progression of the aneurysmal diameter and large diameter (TAAA/AAA $>6-6.5 \mathrm{~cm}$ )

- Symptomatic peripheral artery aneurysm

- Pseudoaneurysm (not suitable for thrombin injection and ultrasonography (US)-guided compression)

PAD

- In the absence of neurological deficit, revascularization is indicated within hours after initial imaging in a case-by-case decision

- Infected arterial prosthesis without overt sepsis hemorrhagic shock, or impending rupture

- Amputations for infection/necrosis and non-salvageable limb

- Symptomatic acute mesenteric ischemia

$\mathrm{AV}$ access for hemodialysis

- Thrombosed or non-functional dialysis access

- Infected access

- AV fistulas revision for ulceration

- Tunneled catheter

Pericardial tamponade or postcardiotomy syndrome with hemodynamically stable patients

LoP III - Emergency (operation before the beginning of the next working day after decision to operate)

CAD

- Patients with a patent ischemia-related artery (IRA) but with unsuitable anatomy for percutaneous coronary intervention (PCI), and either a large myocardial area at jeopardy or with cardiogenic shock.

- Continuing or recurrent ischemia, ventricular arrhythmias, or hemodynamic instability

- Patients with myocardial infarction (MI)-related mechanical complications who require coronary revascularization VHD

- Valve disorder (regurgitation/stenosis/endocarditis) with acute cardiac heart failure

AVD

- TAAA/AAA and peripheral aneurysm with rupture with hemodynamically unstable patients

PAD

- Acute limb ischemia (in the case of neurological deficit)

Dissection of aorta

- Type A aortic dissection

- Complicated type B aortic dissection

Pericardial tamponade or postcardiotomy syndrome with hemodynamically unstable patients

LOP IV - Salvage (patients requiring cardiopulmonary resuscitation en route to the operating theatre or prior to induction of anesthesia)

NSTEMI: Non-ST elevation myocardial infarction; STEMI: ST elevation myocardial infarction; USAP: Unstable angina pectoris 
work uniform, disposable medical protective uniform, disposable latex gloves and full-face respiratory protective devices, or powered air-purifying respirator, if available for COVID-19 patients. ${ }^{[22]}$ A minimum number of surgical team including the anesthesiologist, anesthesia technician, surgeons, scrub nurse, circulating nurse, perfusionist, and OR technician should be assigned before the COVID-19 patient enters the OR. Irrelevant staff should not enter the room to minimize the traffic across the OR. All staff must be protected with proper PPE.

The COVID-19 patient with a N95/surgical mask should be transferred to the COVID-19 OR by the predesignated pathway. All the non-essential equipment should be kept out of the room during induction of anesthesia and intubation. Aerosol-generating procedures such as airway manipulation, face mask ventilation, and open airway suctioning should be performed with great caution. Regional anesthesia is usually preferred over general anesthesia; however, that is not practically possible for open heart surgeries. If regional anesthesia and/or sedation cannot be performed, the patient should always wear a surgical mask during the procedure. Nasal oxygen supply may be administered under the surgical mask. ${ }^{[23]}$

The induction of anesthesia should be carried out by a minimum number of healthcare providers. All the equipment for intubation and drugs used for anesthesia should be ready in the OR before the patient is transferred. Anesthesia induction and preoxygenation should be performed quickly with a wellfitting face mask to minimize the period for mask ventilation. ${ }^{[23]}$ The staff member is recommended to be the most experienced one to intubate the patient to avoid re-attempts. A video laryngoscope is preferred for intubation, if available. ${ }^{[2]}$ Following the inflation of cuff, ventilator is connected to the patient, before positive pressure ventilation is started. Disconnection of the circuit is not recommended. Therefore, closed tracheal suction systems may be used. Anesthesia and intubation protocols have been recently reported by experts..$^{[8,9,20,21]}$

The surgical team including surgeons, scrub nurse, and perfusionist should follow the instructions for PPE (Table 2). Additionally, surgeons and scrub nurse should put on the surgical cap and surgical mask over the PPE and, then, get scrubbed in and put on the surgical coat with double gloves (Figure 2). Gloves must be long-sleeve and should be fixed to the sterile coat with adhesive drapes. All the surgical gowns and gloves must be taken off at the COVID-19 OR. While taking off, firstly take off the second layer of glove and perform hand hygiene. Then, the surgical gown and surgical mask must be taken off. The steps for taking off PPE should be followed at a separated place for doffing.

The transportation of COVID-19 patient should be performed by personnel with PPE. If the patient is intubated during transportation, ventilation is performed by a disposable ambu bag. The positive pressure ventilation should be stopped before disconnection from the ventilator, while placing the patient on the ambu bag. If the patient is extubated, N95/surgical mask should be put on the patient. The ICU bed must be isolated for the COVID-19 patient.

All the equipment used in OR, the floor and wall of OR, and object surfaces should be disinfected and decontaminated by proper procedures. ${ }^{[22]}$ The reusable surgical instruments should be transferred to the nearest washstand (with a COVID-19 warning sign above it) and decontaminated by the personnel wearing PPE. Disinfection via soaking the reusable instruments should be carried out with $1,000 \mathrm{mg} / \mathrm{L}$ chlorinecontaining disinfectant for no-visible contamination and $5,000 \mathrm{mg} / \mathrm{L}$ chlorine-containing disinfectant for any visible contamination for at least $30 \mathrm{~min} .{ }^{[22]}$ All disposable equipment used for the operation should be discarded. All plastic wraps around the equipment should be removed and discarded after the operation. Visible

Table 2. Sequence for donning and doffing personal protective equipment ${ }^{[32]}$

\begin{tabular}{ll}
\hline Donning procedure & Doffing procedure \\
\hline Perform proper hand hygiene & Remove shoe covers (if applicable) \\
Put on shoe cover (if applicable) & Remove gown and gloves together \\
Put on gown & Perform proper hand hygiene \\
Put on mask/respirator (if applicable) & Remove eye protection \\
Put on goggles & Remove mask/respirator (if applicable) \\
Put on gloves & Perform hand hygiene \\
\hline
\end{tabular}




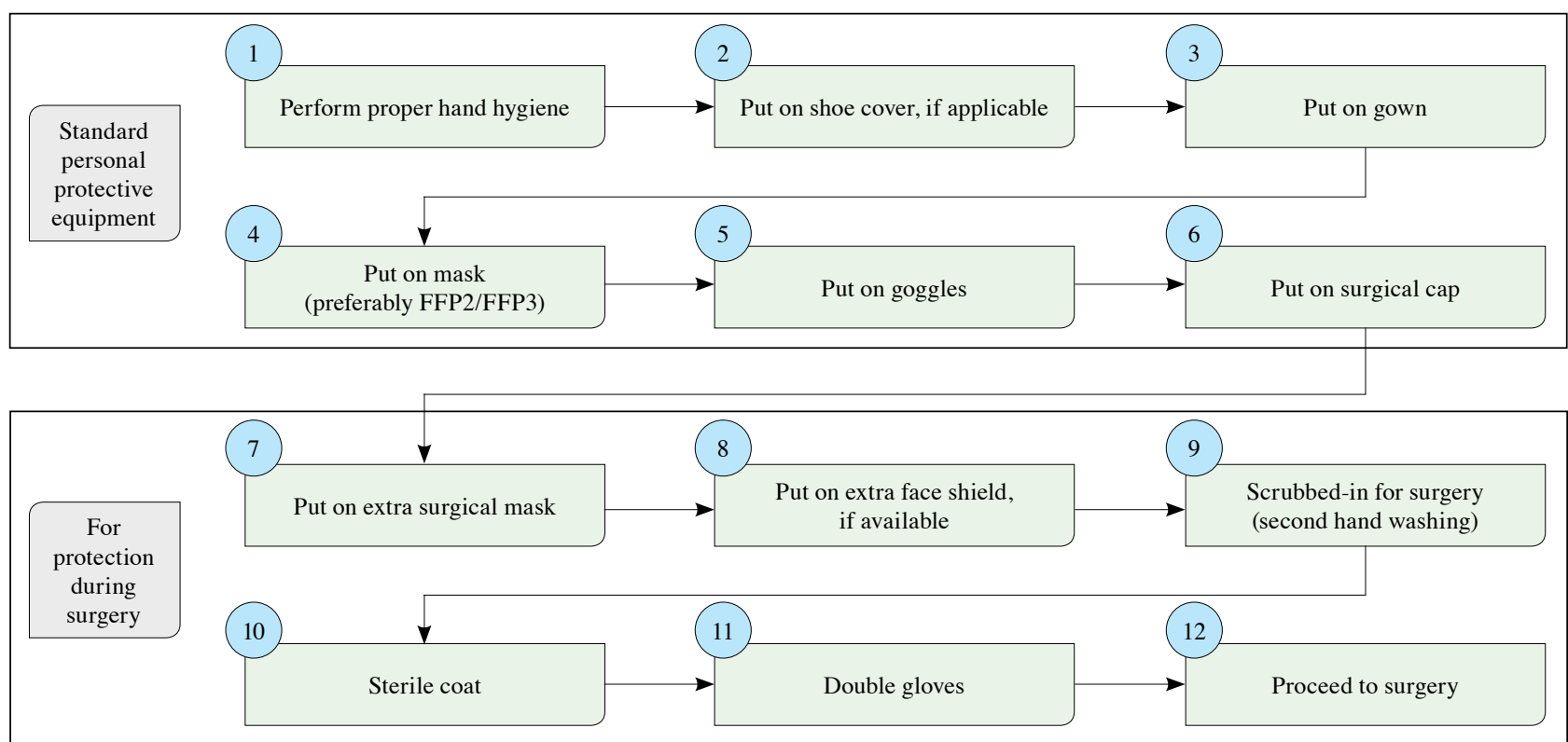

Figure 2. Personal protection equipment during surgery.

contamination on the floors, walls, and object surfaces should be completely removed before disinfection. Disinfection of the floor and walls is carried out with $1,000 \mathrm{mg} / \mathrm{L}$ chlorine-containing disinfection solution by mopping, spraying or wiping, while the object surfaces are wiped with a similar solution. The object surfaces which are not often touched are wiped first; subsequently, frequently touched surfaces are wiped. A 30-min period is necessary for the effective disinfection. Disinfection should be carried out three times a day and whenever the room is contaminated. All the plastic wraps around the equipment should be renewed after decontamination. Plasma air purifiers can be used for air sterilization; otherwise, ultraviolet lamps for one hour can be used. ${ }^{[22]}$

\section{Inflammation during COVID-19 and further potential effects of cardiac surgery}

There is no existing treatment specific for COVID-19. Current therapies are mainly supportive. Development of novel therapies and effective prevention are an urgent need, particularly for life-threatening severe acute respiratory distress syndrome (ARDS) and hyper-inflammatory syndrome (characterized by a fulminant and fatal hypercytokinemia with multi-organ failure). Several cytokines are involved in the disease pathogenesis. ${ }^{[25]}$ Likewise, some of these cytokines induces vascular permeability and leakage, pulmonary edema, dysfunction air exchange, ARDS, acute cardiac injury, and multi-organ failure. ${ }^{[26]}$ Novel therapies such as interleukin (IL) antagonists (dupilumab), JAK2 inhibitor (fetratinib), interferon blockers (e.g., entecavir, penciclovir, sorafenib), and stem cell and mesenchymal cell therapies have been applied to neutralize cytokine storm and offered some improvement. ${ }^{[26-28]}$

Major surgery and anesthesia produce inflammatory and immune response in human beings. In addition, extracorporeal circulation has been presented to be the cause of the main immune response during cardiac surgery. The continuous exposure of blood to the non-endothelial surfaces (perfusion circuit) produces a systemic inflammatory response (i.e., activation of coagulation pathways, complement system, and production of tissue factor and several cytokines). Inflammatory response may be the cause of ARDS and blood transfusion during cardiac may cause transfusion-related acute lung injury (TRALI). ${ }^{[29]}$ Both ARDS and TRALI are hazardous complications which complicate the postoperative period in COVID-19 patients.

The inflammatory response during cardiac surgery occurs due to not only CPB but also surgical trauma, anesthesia, cardioplegia and myocardial ischemia, cardiac manipulation, heparin, and protamine. The control of the inflammatory response to CPB includes off-pump cardiac surgery, arrangement of temperature $\left(32\right.$ to $34^{\circ} \mathrm{C}$ for operations requiring up to $2 \mathrm{~h}$ of $\mathrm{CPB}$ ), heparin coated-perfusion circuits, modified ultrafiltration, complement inhibitors, and glucocorticoids. ${ }^{[30]}$ Other equipment for immune response in cardiac surgery are minimal invasive 
extracorporeal circulation and the cell-saver both of which may have favorable effects on the immune response, reducing the systemic cytokine load. ${ }^{[31]}$

All these measures affecting the immune response and inflammation may be reasonable and should be kept in mind for COVID-19 patients during cardiac surgery.

\section{POSTOPERATIVE MEASURES DURING COVID-19 (SUSPECTED/CONFIRMED) PATIENTS}

During the postoperative follow-up of COVID-19 patients, a cardiac COVID-19 Team with a particular expertise in cardiac ICU including an anesthesiologist, cardiovascular surgeons, pulmonologist, and infectious diseases specialist should be established and decisions should be made jointly. Multidisciplinary decisionmaking among the COVID-19 Team can minimize specialty bias and prevent self-referral from interfering with the optimal patient care.

In patients undergoing cardiovascular surgery, extubation should be planned in the OR for the appropriate patients. Patients to be admitted to the ICU should be transferred in accordance with the infection prevention measures for COVID-19.

Furthermore, there are many documented COVID-19 cases among healthcare workers. Therefore, healthcare workers should follow the infection control policies and procedures already in place at their healthcare institutions. For the healthcare workers performing aerosol-generating procedures in patients with COVID19 in the ICU, it is advisable to use fitted respirator masks (i.e., N95 respirators, FFP2, or equivalent), in addition to other PPE (i.e., gloves, gown, and eye protection, such as safety goggles) as described in the infection prevention measures for COVID-19. ${ }^{[32]}$ If possible, the shift of healthcare workers should be reduced to four hours. Additionally, it is preferentially recommended that performing aerosol-generating, nonaerosol-generating procedures in ICU patients with COVID-19 should be carried out in a negative-pressure room and a portable high-efficiency particulate air filter should be used in the room, if available. In patients who require endotracheal re-intubation, intubation should be performed by the healthcare worker who is the most experienced with airway management to minimize the number of attempts and risk for transmission and using video-guided laryngoscopy over direct laryngoscopy, if available.

During ICU follow-up of COVID-19 patients, patients should be closely monitored for ARDS, systemic inflammatory response syndrome, and cytokine release syndrome.

The preventive and treatment options (including antiviral treatment strategy which is subject to change) related to the diseases itself and subsequent serious clinical conditions (i.e., ARDS or shock) should be taken in accordance with the guideline recommendations. ${ }^{[4,33]}$

In conclusion, in the light of these data, deferrable (Level of Priority I) cardiovascular surgical procedures must be identified by the Heart Team and consent of the patient should be sought. The other procedures (Level of Priority II-IV) should be performed with great caution. Strict measures for infection prevention and extreme attention for healthcare providers should be given in consideration for the management of coronavirus disease-2019 patients.

\section{Declaration of conflicting interests}

The authors declared no conflicts of interest with respect to the authorship and/or publication of this article.

\section{Funding}

The authors received no financial support for the research and/or authorship of this article.

\section{REFERENCES}

1. Wu Y, Ho W, Huang Y, Jin DY, Li S, Liu SL, et al. SARS$\mathrm{CoV}-2$ is an appropriate name for the new coronavirus. Lancet 2020;395:949-50.

2. World Health Organization. WHO announces COVID19 outbreak a pandemic. http://www.euro.who.int/en/ health-topics/health-emergencies/coronavirus-covid-19/ news/news/2020/3/who-announces-covid-19-outbreak-apandemic. [Accessed: April 02, 2020]

3. World Health Organization. Coronavirus disease (COVID19) Pandemic. https://www.who.int/emergencies/diseases/ novel-coronavirus-2019 [Accessed: March 28, 2020]

4. T.C. Sağlık Bakanlığı Halk Sağlı̆̆ı Genel Müdürlüğü COVID-19 Rehberi. https://covid19bilgi.saglik.gov.tr/tr/ and https://covid19bilgi.saglik.gov.tr/depo/rehberler/COVID-19_ Rehberi.pdf. [Accessed: April 02, 2020]

5. Center for Disease Control and Prevention Website. Coronavirus (COVID-19). Available at: https://www.cdc.gov/ coronavirus/2019-nCoV/index.html. [Accessed: March 28, 2020]

6. Chen X, Liu Y, Gong Y, Guo X, Zuo M, Li J, et al. Perioperative Management of Patients Infected with the Novel Coronavirus: Recommendation from the Joint Task Force of the Chinese Society of Anesthesiology and the Chinese Association of Anesthesiologists. Anesthesiology 2020. [Epub ahead of print]

7. Meng L, Qiu H, Wan L, Ai Y, Xue Z, Guo Q, et al. Intubation and Ventilation amid the COVID-19 Outbreak: Wuhan's Experience. Anesthesiology 2020. [Epub ahead of print] 
8. Zhang HF, Bo LL, Lin Y, Li FX, Sun SJ, Lin HB, et al. Response of Chinese Anesthesiologists to the COVID-19 Outbreak. Anesthesiology. 2020. [Epub ahead of print]

9. Türk Anestesiyoloji ve Reanimasyon Derneği. COVID19'lu Hasta Yönetimi. Available at: https://www.tard.org.tr/ haberler/1529. [Accessed: March 28, 2020]

10. Wong J, Goh QY, Tan Z, Lie SA, Tay YC, Ng SY, et al. Preparing for a COVID-19 pandemic: a review of operating room outbreak response measures in a large tertiary hospital in Singapore. Can J Anaesth. 2020. [Epub ahead of print]

11. Ti LK, Ang LS, Foong TW, Ng BSW. What we do when a COVID-19 patient needs an operation: operating room preparation and guidance. Can J Anaesth. 2020. [Epub ahead of print]

12. Kamer E, Çolak T. What to do when a patient infected with COVID-19 needs an operation: A pre-surgery, peri-surgery and post-surgery guide. Turk J Colorectal Dis 2020;30:1-8.

13. T.C. Sağlık Bakanlığg Sağlık Hizmetleri Genel Müdürlüğü. Elektif İşlemlerin Ertelenmesi ve Diğer Alınacak Tedbirler. Available at: https://hasta.saglik.gov.tr/TR,64508/elektifislemlerin-ertelenmesi-ve-diger-alinacak-tedbirler.html. [Accessed: April 02, 2020]

14. T.C. Sağlık Bakanlığı Sağlık Hizmetleri Genel Müdürlüğüi. Pandemi Hastaneleri. Available at: https://hasta.saglik.gov.tr/ TR,64565/pandemi-hastaneleri.html. [Accessed: April 02, 2020]

15. American College of Surgeons. COVID-19: Guidance for Triage of Non-Emergent Surgical Procedures. Available at: https://www.facs.org/covid-19/clinical-guidance/triage. [Accessed: April 02, 2020]

16. Neumann FJ, Sousa-Uva M, Ahlsson A, Alfonso F, Banning AP, Benedetto U, et al. 2018 ESC/EACTS Guidelines on myocardial revascularization. Eur Heart J 2019;40:87-165.

17. Baumgartner H, Falk V, Bax JJ, De Bonis M, Hamm C, Holm PJ, et al. 2017 ESC/EACTS Guidelines for the management of valvular heart disease. Eur Heart J 2017;38:2739-91.

18. Wanhainen A, Verzini F, Van Herzeele I, Allaire E, Bown M, Cohnert T, et al. Editor's Choice - European Society for Vascular Surgery (ESVS) 2019 Clinical Practice Guidelines on the Management of Abdominal Aorto-iliac Artery Aneurysms. Eur J Vasc Endovasc Surg 2019;57:8-93.

19. Chen X, Shang Y, Yao S, Liu R, Liu H. Perioperative Care Provider's Considerations in Managing Patients with the COVID-19 Infections. Transl Perioper \& Pain Med 2020; 7:216-24.

20. Orser BA. Recommendations for Endotracheal Intubation of COVID-19 Patients. Anesth Analg 2020. [Epub ahead of print]
21. Zuo MZ, Huang YG, Ma WH, Xue ZG, Zhang JQ, Gong YH, et al. Expert Recommendations for Tracheal Intubation in Critically ill Patients with Noval Coronavirus Disease 2019. Chin Med Sci J 2020. [Epub ahead of print]

22. Liang T, editor. Handbook of COVID-19 Prevention and Treatment. Zhejiang: Zhejiang University; 2020.

23. Kamming D, Gardam M, Chung F. Anaesthesia and SARS. Br J Anaesth 2003;90:715-8.

24. Wax RS, Christian MD. Practical recommendations for critical care and anesthesiology teams caring for novel coronavirus (2019-nCoV) patients. Can J Anaesth 2020.

25. Huang C, Wang Y, Li X, Ren L, Zhao J, Hu Y, et al. Clinical features of patients infected with 2019 novel coronavirus in Wuhan, China. Lancet 2020;395:497-506.

26. Wu D, Yang XO. TH17 responses in cytokine storm of COVID-19: An emerging target of JAK2 inhibitor Fedratinib. J Microbiol Immunol Infect. 2020. pii: S16841182(20)30065-7.

27. Deng X, Yu X, Pei J. Regulation of interferon production as a potential strategy for COVID-19 treatment. Peking: Peking University; 2020.

28. Metcalfe SM. Mesenchymal stem cells and management of COVID-19 pneumonia. Drug Discov Ther 2020.

29. Rong LQ, Di Franco A, Gaudino M. Acute respiratory distress syndrome after cardiac surgery. J Thorac Dis 2016;8:E1177-E86.

30. Hammon JW, Hines MH. Extracorporeal circulation. In: Cohn LH, Adams DH, editors. Cardiac Surgery in the Adult. 5th ed. New York: McGraw-Hill Education; 2018. p. 299-346.

31. Bauer A, Hausmann H, Schaarschmidt J, Scharpenberg M, Troitzsch D, Johansen P, et al. Shed-blood-separation and cell-saver: an integral Part of MiECC? Shed-blood-separation and its influence on the perioperative inflammatory response during coronary revascularization with minimal invasive extracorporeal circulation systems - a randomized controlled trial. Perfusion 2018;33:136-47.

32. Kamu Hastaneleri Genel Müdürlüğü COVID-19 Kişisel Koruyucu Ekipman Giyme ve Çıkarma Talimatı. Available at: https://khgmstokyonetimidb.saglik.gov.tr/TR,64706/ covid--19-kisisel-koruyucu-ekipman-giyme-ve-cikarmatalimati.html [Accessed: April 02, 2020]

33. Surviving Sepsis Campaign: Guidelines on the Management of Critically Ill Adults with Coronavirus Disease 2019 (COVID-19). Available at: https://www.sccm.org/ getattachment/Disaster/SSC-COVID19-Critical-CareGuidelines.pdf [Accessed: March 28, 2020] 